DOI: 10.17707/AgricultForest.62.4.15

\author{
Olga MIEZİTE, Jelena RŪBA, \\ Edgars DUBROVSKIS, Valters VĒRIN̦S̆ ${ }^{1}$
}

\title{
THE REGROWTH CONSERVATION AFTER SELECTION CUTTING OF FOREST STANDS GROWING IN HYLOCOMIOSA SITE TYPE
}

\section{SUMMARY}

Clear cutting and selection cutting are final felling methods. Clear cutting are often used in Latvian forest. The disturbance of biological rhythm in clear cutting areas occurred for several years. Whereas selection cutting is more environmentally friendly, efforts should be made to apply it more in practice. Objectives of this research are to analyse the regrowth conservation after gradual felling in Hylocomiosa forest stands with a different species composition and determine tree health. For dendrometric indicators and gradual selective felling intensity characterization, twelve sample plots with an area of $500 \mathrm{~m} 2$ were established in both forest stands. Plots were surveyed before and after the gradual selective felling. In order to perform an analysis of regrowth, 92 small inventory plots with a radius of $2.82 \mathrm{~m}$ were evaluated. Regrowth trees were counted (conifers from $0.1 \mathrm{~m}$ height and deciduous $-0.2 \mathrm{~m}$ ) and their height was measured, as well as root rot infection was verified. In the Norway spruce mixed stand (7S3P145) felling intensity was $52 \%$ but in the Scots pine mixed stand (5P5S105) respectively $-49 \%$. After felling trees regrowth number of losses account are 53 and $68 \%$. The average height of spruce regrowth trees in both stands after felling was fallen but average height of birch and Scots pine regrowth increased. The differences of regrowth preservation between tree species during selection cutting were significant $(\mathrm{p}=0.016<\alpha=0.05)$. Root rot was not detected in the mixed Scots pine stand, but in spruce stand it was found in $33 \%$ of cases.

Keywords: mixed stand, clear cutting, height, root rot

\section{INTRODUCTION}

Selection cutting as final cutting methods are known and used for a long time in Latvia but popularity in state and private forests is low. Nowadays clear cutting are recognized and more often used when all stand is cut down in one time. Naturally developed forest stand borders often are disassembled using clear cut and instead new forest stand borders in forest array structure are brightly visible and inherited in future (Lūkins and Nikodemus, 2011). Selection cutting can be used more often in future therefore more research is needed. In 2015 final

\footnotetext{
${ }^{1}$ Olga Miezīte, Jel̦ena Rūba (corresponding author: jelena.ruba@llu.lv), Edgars Dubrovskis, Valters Vērinšš, Latvian University of Agriculture, Jelgava, LATVIA.

Paper presented at the $7^{\text {th }}$ International Scientific Agricultural Symposium "AGROSYM 2016".

Notes: The authors declare that they have no conflicts of interest. Authorship Form signed online.
} 
felling area in Latvia was 38876.77 ha; selection cutting was used in $14.4 \%$ of cases or 5594.56 ha and distribution shows that state forest manager used selection cutting in 6.9\% (386.48 ha) and other forest managers in $93.1 \%$ (5208.08 ha) of cases (Forest statistics, 2015).

At this moment are different opinions regarding to optimal time period between cutting repetition; most mentioned is $4-6$ years. Mainly it depends from stand condition after cut and young tree growth rate. Openings after selection cut in stand create different light conditions depending from angle of sun incidence and remaining tree height (Canham et all., 1990). Sometimes is needed urgent separate tree felling before time due to rapid quality decreasing (Rozītis and Lūkins, 2008). Natural stand regeneration is contributed by light condition under tree canopy (Gray and Spies, 1996; Lieffers et all., 1999). Opening enlargement incenses light amount in its center as function of stand opening diameter and surrounding stand tree height (Lieffers et all., 1999). Ecological and visual changes are less significant if selection cutting is managed correctly. Develops continuous forest array with sparse and thick different tree species groups if forest stands are managed using selection cutting and without brightly visible forest stand borders as using clear cutting methods. Selection cutting compared to clear cutting has minimal influence on forest ecosystem as different age and height trees make forest stand stable and resistant as possible (Rozītis and Lūkins, 2008). Using selection cutting in forest stand trees can be felt down in quantity until stand basal area is larger than critical basal area (LRMK, 2012) and owner has no need in artificial stand regeneration (Mangalis, 2004).

Selection cutting usage increases forest stand resistance from pest and disease damage who can endanger certain age specific tree species stands. Ground cover and its biodiversity is preserved; rare moss and arthropods continuous development needed conditions are created (Zviedris, 1949).

Rozītis and Lūkins (2008) have listed main mistakes and their description. Most frequent mistakes are related to windthrow risk incensement due to large intensity selection cutting. Wrong chosen cut down trees change stand and species structure. Selection cutting done in wrong time of year can lead to remaining tree logging damage and pest and disease damage distribution. Too small stand openings decreases natural stand regeneration rate.

Areas in Latvia where clear cutting is forbidden by regulations are used selection cutting methods and they are solution between ecologic, economic and social forest management disagreement (Zdors and Donis, 2011). Selection cutting mainly is used to gain forest stand natural regeneration in forest site type Hylocomiosa with Scots pine or with Norway spruce mix; also in above mentioned forest ecosystem deciduous stands with spruce as regrowth or in second floor in compartments that are planned as spruce and deciduous species mixed stands (Bisenieks, 2003).

Forest as ecosystem has been developing in long way of evolution depending on different natural conditions and processes. To gain success in forest 
management it has to be coherent and adjusted to natural conditions and ecosystem natural structure and dynamics specialty (Bušs, 1981). In this way is provided better forest stand resistanceto windthrow possibility and larger stand durability against pest and disease damage for certain tree species in different stand age. In basis of above mentioned has been highlighted aim to analyze the regrowth conservation after selection cutting of forest stands growing in Hylocomiosa site type.

To realize research aim whereset following objectives: 1) to analyze dendrometric indicators of Scots pine stands before selection cutting; 2) to analyze dendrometric indicators and sanitary state of stand after selection cutting depending on intensity of cutting.

\section{MATERIAL AND METHODS}

Research data was collected in Scots pine (P) Pinus sylvestris L. and Norway spruce (S) Picea abies (L.) H. Karst. two mixed stands of Hylocomiosa forest site type in Vidzeme region (in area of 2.2 ha with species composition 7S3P 144 (Lat: 57.413770; Long: 25.938024) and 10.9 ha - 5P5S 104 (Lat: 57.528539; Long: 27.069571)) with gradual selective felling done in them.

In both forest stands are installed two type of temporary sample plots (hereafter SP); rectangular SP 20x25 m (1 SP on 1 ha of stand area and each 500 $\mathrm{m}^{2}$ ) and round $\mathrm{SP}$ with radius $2.82 \mathrm{~m}\left(25 \mathrm{~m}^{2}\right.$ each and $4 \mathrm{SP}$ on $\left.1 \mathrm{ha}\right)$. Larger temporary SP (12 over two stands together) established in stands characteristic places to measure dendrometric indicators before selection cutting - stand average breast height $(1.3 \mathrm{~m})$ diameter $(\mathrm{DBH})$ and height, average tree crosssection, average tree volume, stand basal area and growing stock and after gradual selective felling - stand residual basal area, growing stock and cutting intensity. On both stand longest diagonal was established 92 round SP for regrowth registration and height measurement (coniferous from $0.1 \mathrm{~m}$ height and deciduous $-0.2 \mathrm{~m}$ ) and also to evaluate sanitary state before and after gradual selective felling. Regrowth height measured with $5 \mathrm{~m}$ long metallic measuring tape (measurement accuracy $\pm 1 \mathrm{~cm}$ ). In each sample plot was cut down one regrowth tree and visually tested for rot in root collar level for determination of sanitary state in stand.

In larger SP with forest caliper was measured DBH (measurement accuracy $\pm 0.1 \mathrm{~cm}$ ), and tree height was measured with VERTEX height meter (measurement accuracy $\pm 0.1 \mathrm{~m}$ ), and trees was divided in Craft crown classes (Kraft, 1884; Miezīte et al., 2013). Empirical data was mathematically treated with Microsoft Office Excel 2013. Tree cross-section (g) in registering sample plot was calculated by Eq. (1):

$$
g=0.7854 \cdot \frac{D^{2}}{10000},(1)
$$

where $D-\mathrm{DBH}(\mathrm{cm})$. Stand basal area $(\mathrm{G})$ was calculated by Eq. (2): 


$$
G=\frac{G_{u z s k . P L}}{L} \cdot 10000,(2)
$$

where $G_{u z s k . P L}-$ summary tree cross-section of registering sample plots $\left(\mathrm{m}^{2}\right) ; L-$ summary area of registering sample plots $\left(\mathrm{m}^{2}\right)$. Average tree stem volume (v) was calculated by Eq. (3) (Liepa, 1996):

$$
v=\psi * L^{\alpha} * D^{\beta \lg L+\varphi},
$$

where $L-$ stem height, (m); $D-\mathrm{DBH},(\mathrm{cm}) ; \psi, \alpha, \beta, \varphi-$ empirically established coefficients (Scots pine $-\psi-1,6541 * 10^{-4}, \alpha-0,56582, \beta-0,25924, \varphi-$ 1,59689; Norway spruce $\left.-\psi-2,3106^{*} 10^{-4}, \alpha-0,78193, \beta-0,34175, \varphi-1,18811\right)$. Growing stock (V) was calculated by Eq. (4):

$$
V=\frac{V_{P L} \cdot 10000}{L},(4)
$$

Felled stand volume $\left(\mathrm{V}_{i z c .}\right)$ in selection cutting was calculated by Eq. (5):

$$
V_{i z c .}=G_{i z c .} \cdot H F
$$

where HF - form height (LRMK, 2014). Gradual selecting felling intensity was calculated by Eq. (6):

$$
I=\frac{V_{i z c .}}{V} \cdot 100
$$

All above mentioned calculations were done with Microsoft Excel 2013 and for description of tree dendrometric indicators and regrowth was used Descriptive statistics function. For comparison of regrowth tree species samples was used ANOVA analysis (Arhipova and Bāliṇa, 1996).

\section{RESULTS AND DISCUSSION}

Woodland natural structure bigger maintaining opportunities are to carry out and consummate nature friendly forestry methods, for example, using selection cutting to maintain diversity, stability and provide forest functions in collective nature and social system which is one of sustainable forest resource management preconditions (Lindenmayer et al., 2006). During first felling time was cut down withered and pest infected trees, windthrow endangered terrain depression spruce trees, also trees shading regrowth and lower Kraft crown classes trees. Mixed stand dendrometric indicators were calculated before and after selection cutting and gathered in table 1 where we can see that in Hylocomiosa Pine mixed stand (5P5S105) average tree cross-section was $0.0630 \pm 0.00416 \mathrm{~m} 3$ but mixed stand basal area $37.2 \mathrm{~m} 2$ ha-1, average tree volume $-0.7184 \mathrm{~m} 3$ and stand growing stock $427 \mathrm{~m} 3$ ha- 1 . Felled stand basal area $16.8 \mathrm{~m} 2$ ha-1 and felled volume - $207 \mathrm{~m} 3$ ha-1. In Hylocomiosa Spruce mixed stand (7S3P145) average tree cross-section was $0.0823 \pm 0.00752 \mathrm{~m} 2$, stand basal area $49.3 \mathrm{~m} 2$ ha-1 and growing stock $631 \mathrm{~m} 3$ ha-1. Felled stand basal area was $26.1 \mathrm{~m} 2$ ha- 1 and felled volume - $325 \mathrm{~m} 3$ ha-1. Felling intensity was $49-$ 
$52 \%$ with what can be achieved sufficient regrowth natural regeneration and growth (Erefur, 2010).

Table 1. Mixed stand dendrometric indicators before and after selection cutting.

\begin{tabular}{|c|c|c|c|c|c|c|c|}
\hline \multirow{2}{*}{$\begin{array}{c}\text { Species } \\
\text { composition } \\
\text { before / after } \\
\text { felling, Age }\end{array}$} & \multicolumn{4}{|c|}{ Before felling } & \multicolumn{2}{|c|}{ Before/ after felling } & \multirow{2}{*}{$\mathrm{I}, \%$} \\
\hline & $\mathrm{D}, \mathrm{cm}$ & $\mathrm{H}, \mathrm{m}$ & $\mathrm{g}_{\text {vid, }}, \mathrm{m}^{2}$ & $\mathrm{v}, \mathrm{m}^{3}$ & $\begin{array}{c}\mathrm{G} \\
\mathrm{m}^{2} \mathrm{ha}^{-1}\end{array}$ & $\begin{array}{c}\mathrm{V} \\
\mathrm{m}^{3} \mathrm{ha}^{-1}\end{array}$ & \\
\hline $5 \mathrm{P} \mathrm{E}_{105} / 10 \mathrm{P}_{105}$ & $\begin{array}{c}28.3 \pm \\
0.92\end{array}$ & $\begin{array}{c}22.8 \pm \\
0.67\end{array}$ & $\begin{array}{l}0.0630 \pm \\
0.00416\end{array}$ & $\begin{array}{l}0.7184 \pm \\
0.00623\end{array}$ & $37.2 / 17.4$ & $427 / 220$ & 48.5 \\
\hline $7 \mathrm{E} 3 \mathrm{P}_{145} / 8 \mathrm{P} 2 \mathrm{E}_{145}$ & $\begin{array}{c}32.3 \pm \\
1.43\end{array}$ & $\begin{array}{c}25.1 \pm \\
0.62\end{array}$ & $\begin{array}{l}0.0823 \pm \\
0.00752\end{array}$ & $\begin{array}{l}1.0779 \pm \\
0.01548\end{array}$ & $49.3 / 23.2$ & $631 / 306$ & 51.5 \\
\hline
\end{tabular}

Captions: $\mathrm{d}$ - average $\mathrm{dbh} \pm$ standard error; $\mathrm{h}$ - average tree height \pm standard error; gvid. - average tree cross-section \pm standard error; $\mathrm{v}-$ average tree stem volume \pm standard error; $\mathrm{v}-$ stand growing stock; i - felling intensity, \%.

Craft crown classes are used to describe tree growth in research stands where trees are divided in 5 classes depending on tree height, diameter and crown projection. All five craft crown classes (pre-dominant (i), dominant (ii), codominant (iii), suppressed (iv) and completely suppressed trees (v)) are represented in both research stands before gradual selecting felling. In both stands scots pine represent $i$, ii un iii craft crown class trees but norway spruce in $5 \mathrm{p} 5 \mathrm{~s} 105$ mixed stand represent ii, iv and $\mathrm{v}$ craft crown class trees and in $7 \mathrm{~s} 3 \mathrm{p} 145$ mixed stand spruce represent even i craft crown class trees. After selective cutting remaining trees in both mixed stands represent $\mathrm{i}$, ii and iii craft crown classes or dominant trees from whom larger part are ii craft crown class trees. During gradual selective cutting were all iv and $\mathrm{v}$ craft crown class and damaged trees felled and also part of i craft crown class trees with large crown that decreased stand openings and reduced sufficient stand regeneration (rozītis and lūkins, 2008).

Regrowth are small trees below stand canopy that will form future stand in specific growth conditions (Bisenieks, 2003), see figure 1.

Mixed hylocomiosa pine stand $(5 \mathrm{p} 5 \mathrm{~s} 105)$ overall regrowth tree number before selective cutting was 1674 trees per ha (spruce, pine, birch) which is two times smaller than in spruce mixed stand but after selective cutting regrowth tree number was only 540 trees per ha (spruce, pine, birch). In spruce hylocomiosa mixed stand $(7 \mathrm{~s} 3 \mathrm{p} 145)$ before selective cutting were counted 3600 regrowth trees per ha (spruce, birch) and after selective cutting 1707 regrowth trees per ha (only spruce). There are significant difference between regrowth tree retention between tree species after gradual selective cutting $(\mathrm{p}=0.030)$.

Regrowth trees are situated irregularly in mixed stands before and after selective cutting. Pine hylocomiosa mixed stand (5p5s105) 11\% sample plot didn't contain regrowth trees before gradual selective cutting but after already 
$42 \%$ of established sample plots. Spruce hylocomiosa mixed stand $(7 \mathrm{~s} 3 \mathrm{p} 145) 7 \%$ sample plot didn't contain regrowth trees before gradual selective cutting but after cutting $20 \%$ of established sample plots. Regrowth decreasing during forest logging is significant and in pine $(5 \mathrm{p} 5 \mathrm{~s} 105)$ mixed stand reaches $68 \%$, while by species: $\mathrm{s}-3 / 5, \mathrm{p}-4 / 5$, but in spruce (7e3p145) mixed stand reaches $53 \%$ ( $\mathrm{s}$ $1 / 2)$. In pine (5p5e105) mixed stand birch regrowth is located in bio groups and not inhibit pine development.

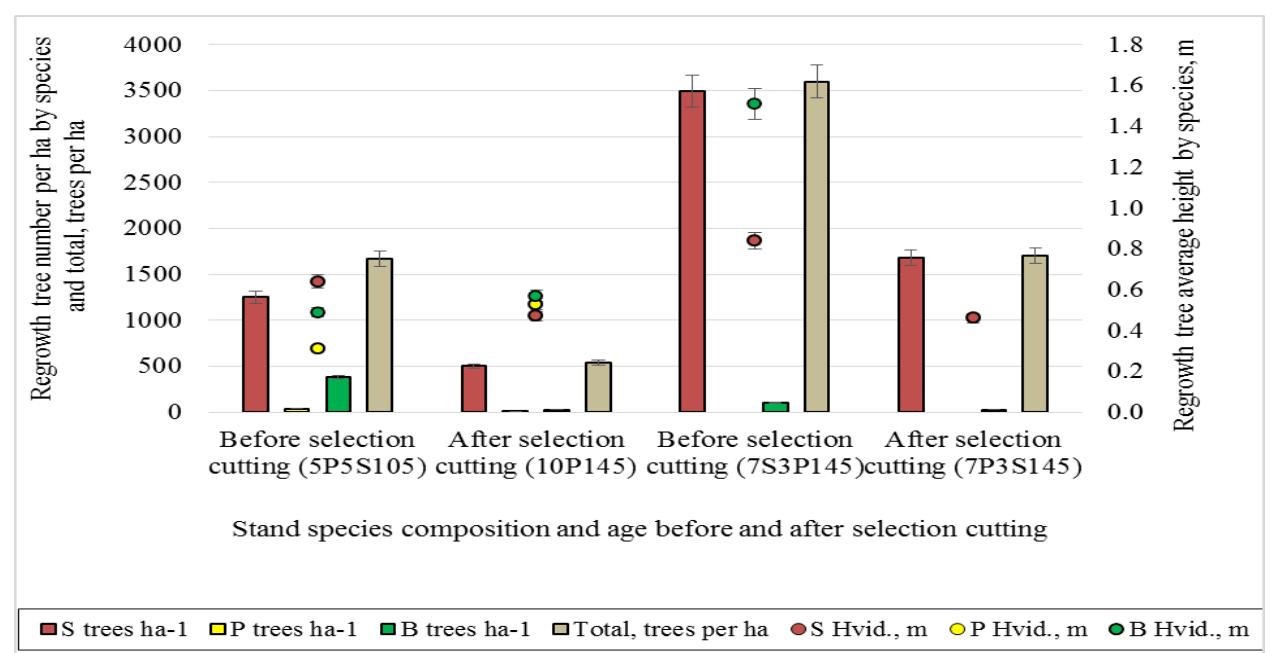

Figure 1. Regrowth trees per ha in Hylocomiosa mixed stands before and after gradual selective cutting and regrowth tree average height

Pine $\left(5 \mathrm{P}_{5} \mathrm{E}_{105}\right)$ mixed stand spruce regrowth tree average height before gradual selective felling was $0.64 \pm 0.038 \mathrm{~m}$ but after felling $0.47 \pm 0.032 \mathrm{~m}$, birch regrowth average height before gradual selective cutting was $0.49 \pm 0.038 \mathrm{~m}$ and after felling $0.57 \pm 0.181 \mathrm{~m}$. Pine regrowth tree average height before gradual selective cutting was $0.31 \pm 0.055 \mathrm{~m}$ but after cutting $0.53 \pm 0.182 \mathrm{~m}$. Spruce regrowth tree average height decrease after gradual selective cutting is result of taller regrowth tree damage during stand logging. Pine and birch regrowth tree average height increased after gradual selective cutting.

Spruce $\left(5 \mathrm{P} 5 \mathrm{E}_{105}\right)$ mixed stand spruce regrowth tree average height before gradual selective felling was $0.84 \pm 0.073 \mathrm{~m}$ but after felling $0.46 \pm 0.029 \mathrm{~m}$, birch regrowth average height before gradual selective cutting was $1.51 \pm 0.59 \mathrm{~m}$ but after cutting birch and pine regrowth trees was not found - they were destroyed during logging process.

During research was estimated occurrence of root rot. In Pine $\left(5 \mathrm{P}^{2} \mathrm{E}_{105}\right)$ mixed stand 77 sample plots were no root rot cases but from 15 Spruce $\left(7 \mathrm{E} 3 \mathrm{P}_{145}\right)$ mixed stand sample plots in 5 of them ( $33 \%$ ) was estimated root rot cases and it can be explained by stand species composition -relatively more spruce trees who are less resistant to root rot than pine trees. 


\section{CONCLUSIONS}

In Pine (5P5E105) Hylocomiosa mixed stand gradual selective cutting intensity was $52 \%$ but in Spruce (7E3P145) Hylocomiosa mixed stand $-49 \%$. There are significant difference between regrowth tree retention between tree species after gradual selective cutting $(p=0.030<\alpha=0.005)$, in Pine (5P5S105) mixed stand regrowth tree number decrease reaches $68 \%$, while by species: $\mathrm{S}-$ $3 / 5, \mathrm{P}-4 / 5, \mathrm{~B}-9 / 10$, but in Spruce (7S3P145) mixed stand reaches $53 \%$ (S $1 / 2)$.

Spruce regrowth tree average height is decreased after gradual selective cutting in result of taller regrowth tree damage during stand logging but pine and birch regrowth tree average height increased after gradual selective cutting because more damage was done to shorter regrowth trees.

Regrowth trees are situated irregularly in both mixed stands before and after selective cutting.

In Pine (5P5S105) mixed stand were no root rot cases but in Spruce (7S3P145) mixed stand root rot was recognized in $33 \%$ of cases.

\section{REFERENCES}

Arhipova I., Bālina S. (2006). Statistic economics. Work with SPSS and Microsoft Excel.

Study aid. Second edition. Rīga, Datorzinību centrs. [In Latvian]

Bisenieks J. (2003). Forest encyclopedia. Rīga, Apgāds Zelta Grauds. [In Latvian]

Bušs, M. (1981). Forest ecology and typology. Rīga, Zinātne. [In Latvian]

Canham C., Denslow J., Platt W., Runkle J., Spies T., White P. (1990). Light regimes beneath closed canopies and tree-fall gaps in temperate and tropical forests. Can. J. For. Res., Vol. 20, pp. 620 - 631.

Erefur C. (2010). Regeneration in Continuous Cover Forestry Systems. Doctoral thesis. Swedish University of Agricultural Sciences, Umeå.

Forest statistics (2015). State forest department statistics report. [online] URL: http://www.vmd.gov.lv/valsts-meza-dienests/statiskas-lapas/publikacijas-unstatistika/statistikas-parskati?nid=1810\#jump Accessed on 01/06/2016 [In Latvian]

Gray A., Spies T. (1996). Gap size, within- gap position and canopy structure effects on conifer seedling establishment. Journal of Ecology, Vol. 84, pp. 635 - 645.

Kraft G. (1884). Thinning, felling rules and intense thin of stand. Beitragezur Lehre. Klindworth's Verlag, Hannover, Germany. [in German]

Lieffers V., Messier C., Stadt K., Gendron F., Comeau P. (1999). Predicting and managing light in the understory of boreal forests. Can. J. For. Res. pp. $796-$ 811.

Liepa I. (1996). Growth study. LLU, Jelgava. [In Latvian]

Lindenmayer D., Franklin J., Fischer J. (2006). General management principles and a checklist of strategies to guide forest biodiversity conservation. Biological conservation, No. 131, pp. $433-445$.

LRMK (2012). Regulations of the Cabinet of Ministers of the Republic of Latvia Nr. 935. Tree felling rules in forest area. [online] URL: http://likumi.lv/doc.php?id=253760 Accessed on 01/06/2016. [In Latvian] 
LRMK (2014). Regulations of the Cabinet of Ministers of the Republic of Latvia Nr. 228. Order of damage estimation done to forest. [online] URL: http://www.likumi.lv/doc.php?id=74476 Accessed on 04/06/2016. [In Latvian]

Lūkins M., Nikodemus O. (2011). Vidzeme woodland structure change in 20th century hillock landscape. Latvijas Universitātes raksti, Zemes un vides zinātnes, Rīga, Vol. 762, pp. 7 - 25. [In Latvian]

Mangalis I. (2004). Forest regeneration and implantation. Rīga, et Cetera. [In Latvian]

Miezite O., Okmanis M., Indriksons A., Ruba J., Polmanis K., Freimane L. (2013). Assessment of sanitary conditions in stands of Norway spruce (Picea abies Karst.) damaged by spruce bud scale (Physokermes piceae Schrnk.). iForest, Vol. 6, pp. $73-78$.

Rozītis J., Lūkins M. (2008). Selective cutting. Forest management experience in demonstration areas. SIA Jelgava tipogrāfija, Jelgava. [In Latvian]

Zdors L., Donis J. (2011). Light regime in uniform and group shelterwood cuttings. Mežzinātne, Vol. 24, pp. 41 - 57. [In Latvian]

Zviedris A. (1949). Forest days and state forestry. In: Kalniņa A. and Saksa K. (Eds.) Forest days [Proceedings]. Rīga, Latvijas Valsts izdevniecība. pp. 22 - 31. [In Latvian] 